\title{
Host Defense Mechanisms in Secondary Syphilitic Lesions
}

\author{
A Role for IFN- $\gamma$-/IL-17-Producing CD8 ${ }^{+} T$ Cells?
}

\author{
Georg Stary, ${ }^{*}$ Irene Klein, ${ }^{*}$ \\ Marie-Charlotte Brüggen, ${ }^{*}$ Sabine Kohlhofer, ${ }^{*}$ \\ Patrick M. Brunner, ${ }^{*}$ Daniel Spazierer, ${ }^{*}$ \\ Leonhard Müllauer, ${ }^{\dagger}$ Peter Petzelbauer, ${ }^{\ddagger}$ \\ and Georg Stingl* \\ From the Department of Dermatology, Division of Immunology, \\ Allergy, and Infectious Diseases, ${ }^{*}$ the Department of Clinical \\ Pathology, ${ }^{\dagger}$ and the Department of Dermatology, Division of \\ General Dermatology, ${ }^{\ddagger}$ Medical University of Vienna, Vienna, \\ Austria
}

Cell-mediated immunity is thought to be of critical importance in antisyphilitic host defense, but the exact mechanisms are still unknown. This fact is particularly true for HIV-infected persons with a deficit in $\mathrm{CD}^{+}$T-cell number. We therefore obtained lesional skin samples from $\mathrm{HIV}^{+}$and $\mathrm{HIV}^{-}$patients with secondary syphilis at different time points of lesional age to search both for causative microorganisms and to characterize the inflammatory infiltrate. By doing so, we detected Treponema pallidum spirochetes with a much greater abundance in late lesions of $\mathrm{HIV}^{+}$individuals compared with the HIV $^{-}$cohort. The dominating inflammatory cells were $T$ cells, macrophages, and neutrophils at all stages and plasma cells in older lesions. In $\mathrm{HIV}^{-}$persons, $\mathrm{T}$ cells consisted of equal numbers of $\mathrm{CD}^{+}$and $\mathrm{CD8}^{+}{ }^{-}$-cells, whereas in $\mathrm{HIV}^{+}$ patients, the majority of $T$ cells belonged to the CD8 lineage and produced both IFN- $\gamma$ and IL-17. Regulatory $T$ cells and Langerhans cells were reduced in these patients compared with their HIV $^{-}$counterparts. Because of our observations, we propose that $T$ cells of both the $\mathrm{CD} 4$ and $\mathrm{CD} 8$ lineage are needed for an at least partial protective antisyphilitic immunity. Compensation mechanisms in $\mathrm{HIV}^{+}$individuals, such as an increase of Tc1/17 cells as well as a reduction in immunoregulatory Langerhans cells and $T$ cells, apparently do not overcome the deficiencies in these patients to eliminate the spirochete. (AmJ Pathol 2010, 177:2421-2432; DOI: 10.2353/ajpath.2010.100277)
Syphilis is a multistage sexually transmitted disease that continues to be a public health problem. Natural infection with Treponema pallidum subsp. pallidum (T. pallidum) results in the formation of a primary lesion at the entry site of the bacteria and, after dissemination of the microorganisms to different tissues, in secondary manifestations. A vigorous immune response develops early during infection and causes local clearance of the majority of treponemas. In less than one third of untreated syphilitic patients, the infection can progress after a latency phase to tertiary syphilis with skin, bone, cardiovascular, and/or neurological involvement. ${ }^{1}$

The inability to cultivate T. pallidum in vitro, coupled with difficulties to establish suitable animal models for immunological studies, has greatly hindered our understanding of the basic aspects of syphilis. Evidence for the importance of a strong cellular immunity evolved first from studies in a rabbit model of syphilis, as i) T. pallidum can induce an antigen-specific proliferation of T-cells a few days to months after infection, ${ }^{2,3}$ ii) activated macrophages and the infiltration of mononuclear cells at the site of inoculation of the bacteria correlate with T. pallidumreactive T-cells, ${ }^{4,5}$ and iii) high levels of IL-2 and IFN- $\gamma$ can be detected after incubation of splenocytes with particles of $T$. pallidum. ${ }^{3}$ In human skin samples of primary and secondary syphilis, the dominance of T-cells and macrophages and IL-2, IFN- $\gamma$, and IL-12 as classical Th1 cytokines has been demonstrated. ${ }^{6,7}$ However, the exact cellular subset responsible for pathogen clearance has yet to be found. CD4 ${ }^{+}$T-cells are believed to mediate the eradication of treponema primarily through the production of cytokines, such as IFN- $\gamma$, thereby activating

\footnotetext{
The work for this article was performed at the Division of Immunology, Allergy and Infectious Diseases of the Department of Dermatology, Medical University of Vienna, Vienna, Austria without additional funding.

Accepted for publication July 1, 2010.

Address reprint requests to Georg Stary, M.D., Department of Dermatology, Division of Immunology, Allergy, and Infectious Diseases (DIAID), Medical University of Vienna, Währinger Gürtel 18-20, 1090 Vienna, Austria. E-mail: georg.stary@meduniwien.ac.at.
} 
macrophages, ${ }^{8}$ which presumably then kill opsonized spirochetes. ${ }^{9,10}$ Other studies suggest that activated $\mathrm{CD}^{+} \mathrm{T}$-cells participate in the local pathogen clearance. ${ }^{6,11}$ Recently published data of suction blisters of syphilitic skin lesions and peripheral blood mononuclear cells show that $T$. pallidum simultaneously elicits also innate immune responses, ${ }^{12,13}$ as evidenced by the direct activation of macrophages by $T$. pallidum-derived TLR2 ligands. ${ }^{14}$

In this study we aimed at carefully characterizing the tissue-based inflammation during secondary syphilis and at defining candidate effector cells in pathogen clearance.

\section{Materials and Methods}

\section{Patients and Tissue Material}

Twenty-five patients with serologically confirmed secondary syphilis and cutaneous involvement (2 females, 23 males; mean age $49.7 \pm 16.2$ ) were enrolled in the study. All patients were recruited in the STD and HIV outpatient center of the Department of Dermatology, Medical University of Vienna. Diagnoses were made by trained physicians and with laboratory confirmation. All patients were serologically positive for the Treponema pallidum particleagglutination assay (TPPA), fluorescent treponemal antibody absorbed (FTA-ABS), and Venereal Disease Research Laboratory (VDRL) tests. Routinely, the patients' history with the time of lesional persistence and the HIV-1 status were assessed and documented. Thirteen of 25 patients were HIV-infected (12 men, 1 woman; mean age $44 \pm 9$ years, range $36-62$ years; mean $\mathrm{CD} 4^{+}$cell count: $465.9 \pm 195.4 \mathrm{cells} / \mu \mathrm{l}$, range $228-808 \mathrm{cells} / \mu \mathrm{l}$; mean viral load: $182,975 \pm 275,459 \mathrm{copies} / \mathrm{ml}$, range $50-$ 724,436 copies $/ \mathrm{ml}$ ). Three $\mathrm{HIV}^{+}$individuals received antiretroviral therapy resulting in a viral load of less than 50 RNA copies/ml plasma. According to the CDC classification of HIV infection two patients belonged to category $A 1$, six to $A 2$, four to $A 3$, and one to $B 2$ at the time point of diagnosis. Syphilitic skin manifestations and locations were classified as localized papules (eg, palmoplantar, genital, facial papules, condylomata lata, plaques muqueuses) and/or as generalized rash on trunk and limbs, Skin biopsies were taken from the trunk $(n=14)$, from upper extremities $(n=7)$, or from lower extremities $(n=$ 4) before antibiotic therapy. From each patient a punch biopsy was taken under local anesthesia and divided into two or three pieces for formalin and trizol fixation and, in 14 cases, for embedding in optimal cutting tissue (OCT) compound (Tissue-Tek) and subsequent deep-freezing in liquid nitrogen. Trizol-fixed and deep-frozen tissue specimens were stored at $-20^{\circ} \mathrm{C}$ and $-80^{\circ} \mathrm{C}$, respectively, until further processing. Normal skin samples from healthy individuals $(n=10)$ were used as the control group.

The study was performed according to the Declaration of Helsinki. All study subjects participated voluntarily and gave informed consent; the study was approved by the Ethics Committee of the Medical University of Vienna (EK 721/2008).

\section{Histopathological Evaluation}

A routine hematoxylin and eosin (HE) staining was performed on all formalin-fixed biopsy specimens $(n=$ 25) and evaluated blindly by one of the co-authors (P.P.) with a scoring system for the following panel of histopathological features: epidermal acanthosis (0 denotes $<0.15 \mu \mathrm{m}, 1$ denotes $0.15-0.3 \mu \mathrm{m}, 2$ denotes $>0.3 \mu \mathrm{m})$; dyskeratosis of keratinocytes ( 0 , absent; 1 , present); occurrence of plasma cells, macrophages, and neutrophils $(0$, absent; 1 , single; $2,<20 \%$ of inflammatory cells; $3,>20 \%$ of inflammatory cells); nodular infiltrate (0, absent; 1 , present); vasculitis (occlusion of vessels by fibrin and erythrocytes: 0 , absent; 1 , present); endothelial cell proliferation (0, absent; 1 , present); extravasation of red blood cells ( 0 , absent; 1, present).

\section{Quantitative RT-PCR}

Trizol-fixed frozen biopsies $(n=25)$ were thawed on ice and then homogenized with a FastPrep-24 homogenizer (MP Biomedicals; Solon, OH) for RNA isolation according to the manufacturer's instructions. The RNA concentration was determined with a NanoDrop ND-100 spectrophotometer (Peqlab Biotechnology; Erlangen, Germany) followed by the removal of DNA by TURBO DNase (Applied Biosystems; Foster City, CA) treatment according to the manufacturer's guidelines. The reverse transcription of RNA to cDNA was performed with a High-Capacity cDNA Reverse Transcription Kit (Applied Biosystems) according to the standard protocol for a $20 \mu$ l reaction on a Thermocycler Perkin Elmer 480 (Perkin Elmer; Waltham, $M A)$. The reactions were amplified and quantified by a TaqMan Universal PCR Master Mix (Applied Biosystems) on an Applied Biosystems ABI PRISM 7700 using the following thermal cycler conditions: 2 minutes at $50^{\circ} \mathrm{C} ; 10$ minutes at $95^{\circ} \mathrm{C}$; and 40 cycles of 15 seconds at $95^{\circ} \mathrm{C}$ followed by 60 seconds at $60^{\circ} \mathrm{C}$. The human $\beta-2$-microglobulin $(\beta 2 \mathrm{~m})$ gene (Hs00187842_m1, Applied Biosystems), a housekeeping gene, was used to normalize each sample and each gene. For the primers and probes for the TaqMan RT-PCR assays we used TaqMan Gene Expression Assays (all Applied Biosystems): IL-12p35, Hs01073447_m1; IL-12/IL-23p40, Hs01011518_m1; IL-23p19, Hs00413259_m1; IFN- $\gamma, \quad H s 00174143 \_m 1 ;$ IL-4, Hs00929862_m1; IL-13, Hs99999038_m1; IL18, Hs99999040_m1; IL-17, Hs00174383_m1; IL-22, Hs01574154_m1; IL-10, Hs00961622_m1; and TGF- $\beta$, Hs00171257_m1. The data were analyzed and samples were quantified by software provided with the Applied Biosystems ABI PRISM 7700 (Sequence Detection Systems, ver. 1.7) and calculated using the comparative $\mathrm{C}_{\mathrm{T}}$ method with $\beta 2 \mathrm{~m}$ as reference gene relative to normal skin. For quantitative analysis of $T$. pallidum amplification of the 16s-rDNA T. pallidum gene was performed (accession number of the GenBank NCBI: AE000520.1). 
Table 1. List of Antibodies Used in this Study

\begin{tabular}{|c|c|c|}
\hline $\begin{array}{l}\text { Antibody } \\
\text { specificity }\end{array}$ & $\begin{array}{c}\text { Clone } \\
\text { (source of antibodies) }\end{array}$ & Isotype \\
\hline BDCA-2 (pur.) & $\begin{array}{l}\text { 124B3.13 (Dendritics, } \\
\text { Lyon, France) }\end{array}$ & mlgG1 \\
\hline CD1a (FITC) & $\begin{array}{l}\text { HI149 (BD Bioscience, } \\
\text { Schwechat, Austria) }\end{array}$ & mlgG1 \\
\hline CD1c (pur.) & $\begin{array}{l}\text { M241 (Ancell, Bayport, } \\
\text { MN) }\end{array}$ & mlgG1 \\
\hline CD3 (FITC) & SK-7 (BD Bioscience) & mlgG1 \\
\hline CD4 (pur.) & SK-3 (BD Bioscience) & mlgG1 \\
\hline CD8 (pur.) & $\begin{array}{l}\text { C8/144B (DakoCytomation, } \\
\text { Glostrup, Denmark) }\end{array}$ & mlgG1 \\
\hline CD8 (APC) & $\begin{array}{l}\text { B9.11 (Immunotech Coulter, } \\
\text { Brea, CA) }\end{array}$ & mlgG1 \\
\hline CD11b (FITC) & $\begin{array}{l}\text { BEAR1 (Beckman Coulter, } \\
\text { Brea, CA) }\end{array}$ & mlgG1 \\
\hline CD14 (pur.) & MФP9 (BD Bioscience) & $\mathrm{mlgG} 2 \mathrm{~b}$ \\
\hline CD19 (pur.) & SJ25C1 (BD Bioscience) & mlgG1 \\
\hline CD25 (pur.) & 2A3 (BD Bioscience) & mlgG1 \\
\hline CD56 (biot.) & B158 (BD Bioscience) & mlgG1 \\
\hline CD123 (biot.) & 9F5 (BD Bioscience) & mlgG1 \\
\hline CD138 (pur.) & Ml15 (BD Bioscience) & mlgG1 \\
\hline CD207 (pur.) & DCGM4 (Beckman Coulter) & mlgG1 \\
\hline FoxP3 (biot.) & $\begin{array}{l}\text { 236A/E7 (eBioscience, } \\
\text { San Diego, CA) }\end{array}$ & mlgG1 \\
\hline $\begin{array}{l}\text { HLA-DR } \\
\quad(\text { FITC, APC) }\end{array}$ & L243 (BD Bioscience) & $\mathrm{mlgG} 2 \mathrm{a}$ \\
\hline IFN- $\gamma$ (biot.) & $\begin{array}{l}\text { B27 (Abcam, } \\
\text { Cambridge, MA) }\end{array}$ & mlgG1 \\
\hline IL-17A (pur.) & eBio64DEC17 (eBioscience) & mlgG1 \\
\hline $\begin{array}{l}\text { T. pallidum } \\
\text { (pur.) }\end{array}$ & $\begin{array}{l}\text { Rabbit polyclonal Ig to } \\
\text { T. pallidum (Abcam) }\end{array}$ & $\begin{array}{l}\text { Rabbit Ig } \\
\text { polyclonal }\end{array}$ \\
\hline
\end{tabular}

biot., biotinylated; pur., purified; APC, allophycocyanin. globulins (DAKO) served as negative control. To prevent nonspecific protein binding, antibodies were mixed with normal horse serum and 2\% BSA in PBS (Gibco, Carlsbad, CA) before being applied to the sections at $4^{\circ} \mathrm{C}$ overnight. After incubation of the slides with biotinylated horse anti-rabbit IgG (Vector Laboratories, Burlingame, $\mathrm{CA})$ at room temperature for 45 minutes, the sections were rinsed and incubated with avidin-biotin peroxidase complex (Vector Laboratories) at room temperature for 45 minutes. For visualization of the cells, $0.01 \% 3$-amino9-ethyl-carbazol in $50 \mathrm{mmol} / \mathrm{L}$ acetate buffer $(\mathrm{pH} 5$, $0.015 \% \mathrm{H}_{2} \mathrm{O}_{2}, 5 \%$ dimethylformamide) was used as chromogen. Sections were counterstained with hematoxylin (Merck, Darmstadt, Germany) and mounted in Aquamount (BDH Laboratory Supplies, Poole, UK). Treponemas were enumerated as spiral or punctual structures per visual field and expressed as the number treponemas per millimeter basement membrane as well as of treponemas per millimeter ${ }^{2}$ dermis \pm SEM.

\section{Statistical Analysis}

The significance of the differences in cellular and treponema numbers between $\mathrm{HIV}^{+}$and $\mathrm{HIV}^{-}$patients was verified by the nonparametric Mann-Whitney $U$ test. The levels of significance of data from quantitative RT-PCR analysis were assessed by the parametric Students $t$ test. A $P$ value of $<0.05$ was considered as statistically significant.

\section{Results}

\section{Staining}

Single and multicolor immunofluorescence staining procedures were performed on frozen sections of patients with secondary syphilis $(n=14)$ and healthy controls $(n=10)$ as previously described. ${ }^{15}$ The mAbs used in this study and their sources are shown in Table 1. Cytokine stainings for IFN- $\gamma$ and IL-17 were performed using a tyramide signal amplification (TSA) system (PerkinEImer, Waltham, MA) according to the manufacturer's suggestions. Negative controls were obtained in all staining experiments by substituting isotype-matched IgG or IgM (purified, APC-, or FITC-labeled) for the primary antibody. For the evaluation of immunofluorescence results biopsy specimens were read in a blinded fashion by two independent investigators with a mean observer coefficient of $<10 \%$. Labeled cells were enumerated per visual field and expressed as the number of epidermal cells per millimeter basement membrane as well as of cells per millimeter ${ }^{2}$ dermis \pm SEM.

Paraffin sections of all 25 patients were used to visualize $T$. pallidum by immunohistological stainings after paraffin dewaxing and antigen retrieval. To determine the distribution and the number of $T$. pallidum in lesional skin, single immunostainings were performed with a polyclonal rabbit-anti-T. pallidum antibody (Abcam). Substitution of the antibody with concentration-matched rabbit immuno-

\section{Clinical Characterization of Secondary Syphilitic Lesions According to the Duration of Their Persistence}

Twenty-five patients with secondary syphilis, 13 thereof being HIV-positive, were classified into four categories according to the age of their lesions: six patients with an early rash being present for not longer than 10 days; six individuals with a rash of 11-20 days duration; seven persons with skin symptoms persisting for 21-30 days, and, finally, six patients with papules having appeared 30 days ago or even longer. Differences in the clinical presentation resulted from the duration of lesional persistence: a slightly erythematous maculo-papular rash without apparent scaling was typical for early lesions of less than 10 days duration (Figure 1A); when persisting longer, the skin manifestations became more infiltrated and exhibited a violaceous color and showed signs of epidermal involvement (Figure 1B). With an age of $>20$ days, the individual papules had often coalesced to scaling plaques that often displayed a psoriasiform appearance and configuration (Figure 1, C and D). In general, the extent of skin involvement was more pronounced in $\mathrm{HIV}^{+}$patients (table 2). 


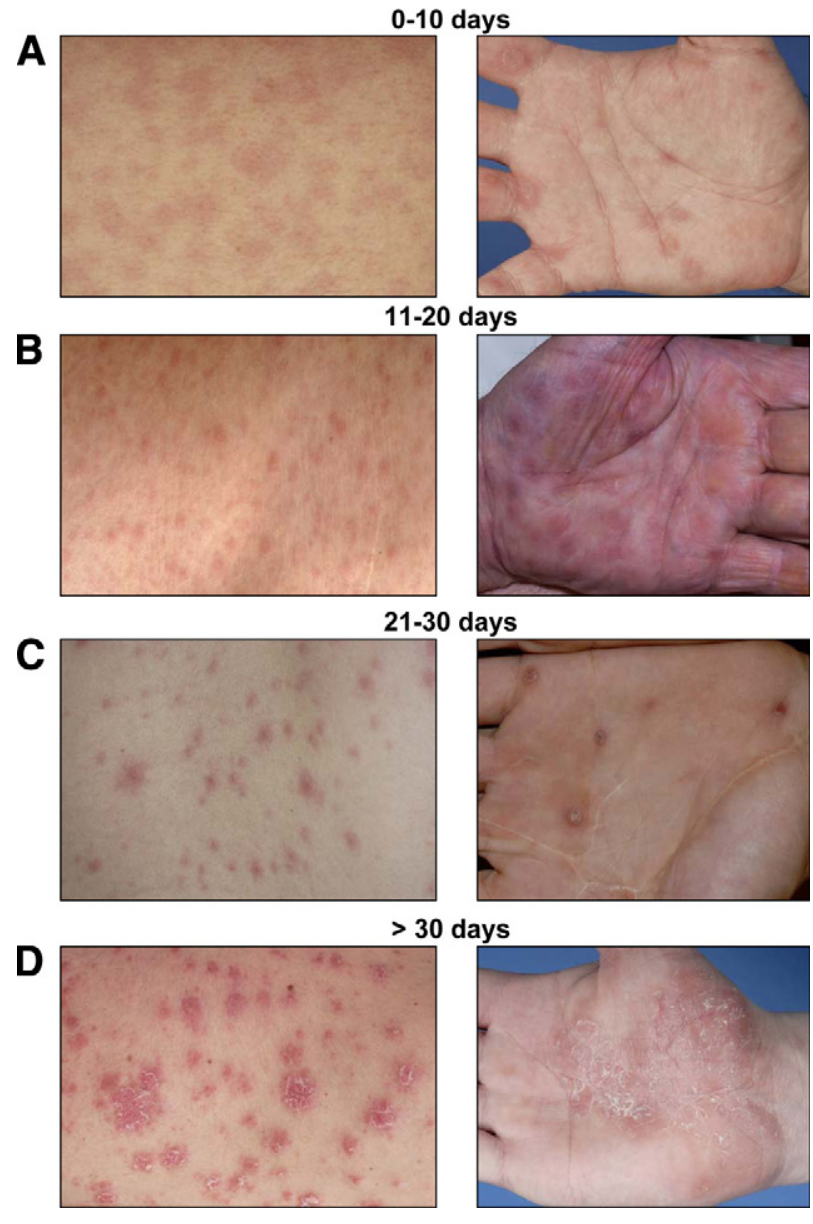

Figure 1. Correlation of clinical symptoms and lesional age of secondary syphilitic eruptions. Patients were arbitrarily divided into four groups according to the length of persistent lesions [(A) 10 days or less, $n=6$; (B) 11 to 20 days, $n=6$; (C) 21 to 30 days, $n=7$; (D) more than 30 days, $n=6$ ]; type as well as severity of these lesions were recorded. The clinical pictures are representative of the indicated times.

\section{Histopathological Findings of Syphilitic Lesions: A Time-Dependent Process}

Histopathological examination of the 25 secondary syphilitic lesions revealed a pattern that correlated with the duration of the lesions (Figure 2, A-H), but not with the HIV status of the patients. In lesions existing for fewer than 10 days, the typical histopathological picture was a sparse perivascular lymphocytic infiltrate, with few neutrophils and macrophages admixed, but devoid of plasma cells, in the upper dermis and an overt vacuol-

Table 2. Extent of Skin Involvement in $\mathrm{HIV}^{+}$and $\mathrm{HIV}^{-}$ Syphilitic Patients

\begin{tabular}{ccc}
\hline & $\begin{array}{c}\text { HIV-positive } \\
(n=13)\end{array}$ & $\begin{array}{c}\text { HIV-negative } \\
(n=12)\end{array}$ \\
\hline $\begin{array}{c}\text { Localized papules } \\
\text { in } \leq 2 \text { sites }\end{array}$ & 5 & 6 \\
$\begin{array}{c}\text { Localized papules } \\
\text { in }>2 \text { sites }\end{array}$ & 6 & 2 \\
$\begin{array}{c}\text { Generalized rash } \\
\text { Localized and generalized } \\
\text { manifestations }\end{array}$ & 10 & 7 \\
\hline
\end{tabular}

ization of the basal cell layer of the epidermis mimicking multiforme-like drug eruptions (Figure 2, A and G). Plasma cells were first found 10-20 days after appearance of the rash and gradually increased in numbers with the age of the lesion (Figure 2G). At this early stage, the differential diagnosis with pityriasis lichenoides may be difficult, especially in cases when plasma cells are still few in number. On longer duration of the lesions, the infiltrate became nodular and involved the superficial and deep vascular plexus (Figure 2, B-D and $\mathrm{H}$ ). In addition to lymphocytes and neutrophils, the plasma cell became a dominant component (Figure 2G). Subsequently, by the admixture of macrophages, the infiltrate exhibited a granulomatous appearance (Figure 2, C, D, and H). In papules of more than 20 days duration a psoriasiform pattern was observed, manifested by epithelial acanthosis, papillomatosis, and parakeratosis as well as dyskeratotic cells within the basal and suprabasal layers (Figure 2, C-F). In early stages the epidermis contained Iymphocytes, whereas the proriasiform hyperplastic epithelium of lesions with more than 20 days duration also contained neutrophils, thereby mimicking psoriasis or epidermomycosis (Figure 2, A-D). A very important histological feature is the involvement of postcapillary venules, which is seen after day ten (Figure 2, A-D). Vessels were occluded by erythrocyte thrombi or even by fibrin thrombi, the endothelial cells were swollen and contained prominent nuclei. Such vessels were always surrounded by extravasated red blood cells. However, this type of vessel involvement can be clearly distinguished from leukocytoklastic vasculitis, where fibrin-occluded vessels are permeated and surrounded by neutrophils and nuclear dust.

\section{IFN- $\gamma$ as Key Cytokine in Syphilitic Lesions: Differences between $\mathrm{HIV}^{+}$and HIV ${ }^{-}$Patients}

Although we could not detect transcripts for the classical Th1 cytokines IL-12p35 or IL-18, quantitative RT-PCR revealed a strong up-regulation of IFN- $\gamma$ mRNA in syphilitic skin lesions as compared to healthy skin (Figure 3A). Our studies further revealed a strong "Th17" signature, as evidenced by elevated levels of IL-23p19, IL-17, and IL-22 mRNA (Figure 3B). In contrast, stage 2 syphilitic lesions were essentially devoid of transcripts for the Th2 cytokines IL-4 and IL-13 (Figure 3C). When we analyzed the lesional cytokine levels with regard to the patients' HIV status and time of lesional persistence, we observed significant differences between $\mathrm{HIV}^{+}$and $\mathrm{HIV}^{-}$patients (Figure 3, A-C) but not between lesions of different duration (Figure 3, D-F). IFN- $\gamma$ expression was more than doubled in HIV-infected individuals (Figure 3A), and IL23p19 as well as IL-17 and IL-22 transcripts were several fold more up-regulated in $\mathrm{HIV}^{+}$patients as compared to $\mathrm{HIV}^{-}$individuals. We further observed a tendency for reduced levels of the regulatory cytokines $\mathrm{IL}-10$ and TGF- $\beta$ in $\mathrm{HIV}^{+}$patients as compared to $\mathrm{HIV}^{-}$individuals (Figure $3 \mathrm{C}$ ). These data suggest that T-cells producing cytokines originally described for Th1 and Th17 cells are operative against $T$. pallidum in secondary syphilitic le- 
A

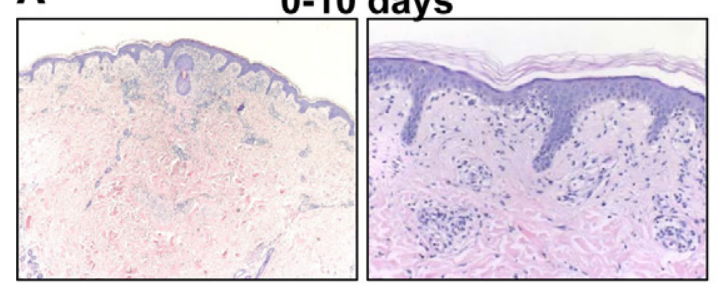

C

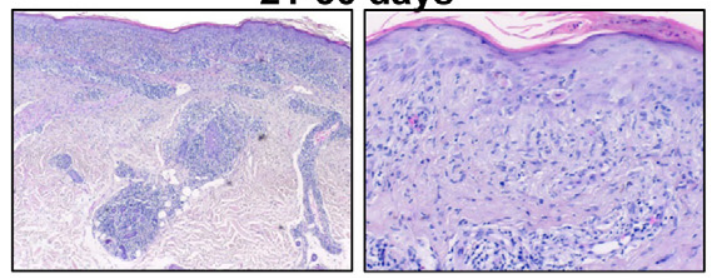

E

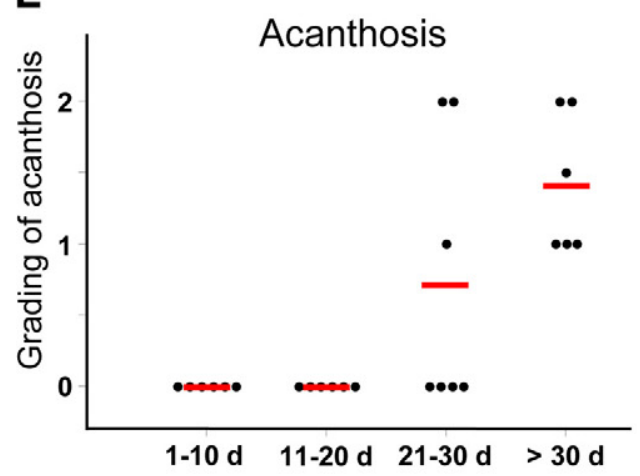

G

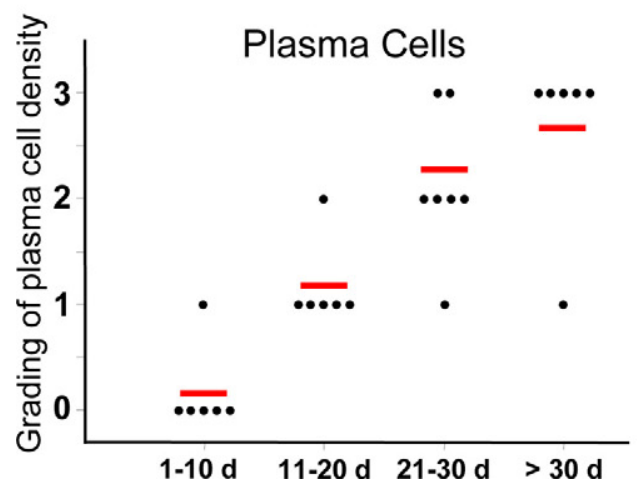

B

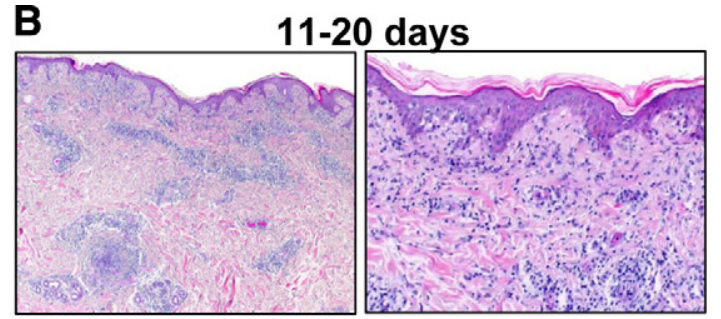

D

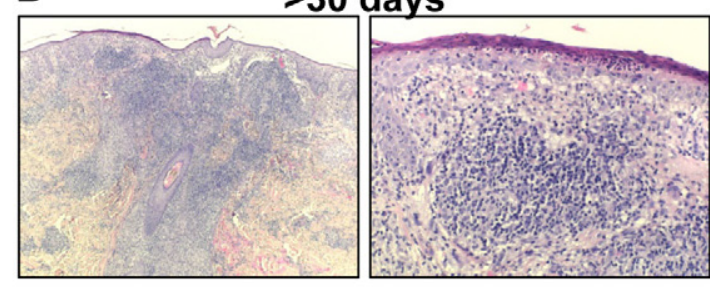

$\mathbf{F}$

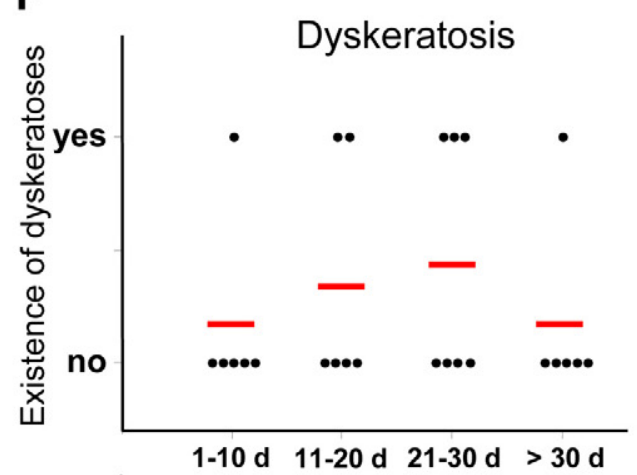

H

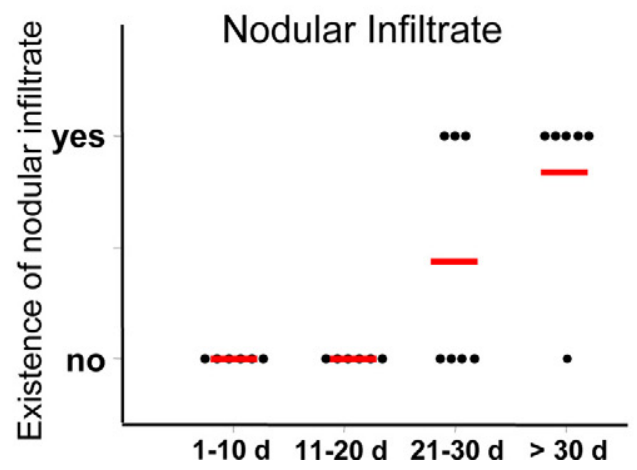

Figure 2. Histopathological correlation with the lesional age of secondary syphilitic skin eruptions. Histopathological changes are displayed analogous to clinical alterations in four groups according to lesional persistence. Representative pictures with a magnification $\times 100$ and $\times 400$ are shown for lesional persistence of four different times: $(\mathbf{A})$ 0-10 days $(n=6),(\mathbf{B}) 11-20$ days $(n=6),(\mathbf{C}) 21-30$ days $(n=7)$, and $(\mathbf{D})$ more than 30 days $(n=6)$. Quantifications of epidermal and dermal alterations are shown in $\mathbf{E}-\mathbf{H}$.

sions and that such an immune response is amplified in HIV-infected patients.

\section{Composition of the Leukocyte Infiltrate in Syphilitic Lesions of HIV ${ }^{+}$and HIV ${ }^{-}$Patients}

Of 25 syphilitic patients that were included into the study, we obtained snap frozen tissue specimens from 14 patients, seven thereof $\mathrm{HIV}^{+}$, that were subjected to immunofluorescence analysis using a broad panel of antibod- ies listed in Table 1. Normal skin from 10 healthy donors served as control (healthy controls, HC). In stage 2 syphilitic lesions we found the infiltrate to be dominated by $\mathrm{CD}^{+}$cells with comparatively higher numbers in HIVinfected patients. This increase of $\mathrm{CD}^{+}$cells in $\mathrm{HIV}^{+}$ individuals affected mainly the $\mathrm{CD}^{+} \mathrm{T}$-cell subset (Figure 4, A and B). Regulatory T-cells, visualized by CD25/ FoxP3/CD3 triple stainings, were increased in the dermis of $\mathrm{HIV}^{-}$patients as compared with normal skin from $\mathrm{HC}$ and $\mathrm{HIV}^{+}$individuals (Figure 4, C and D). 
A

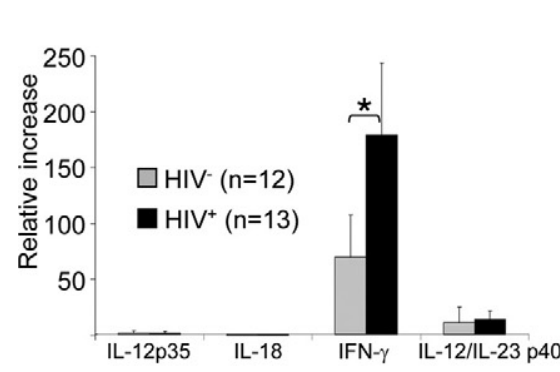

D

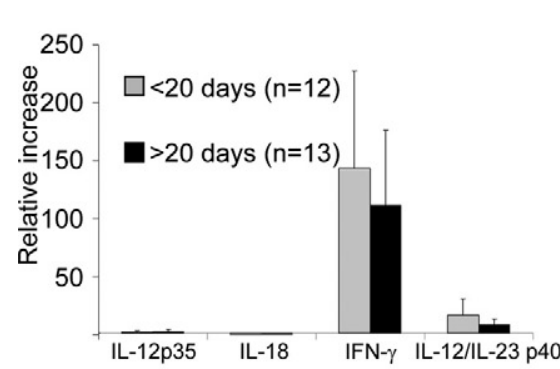

B

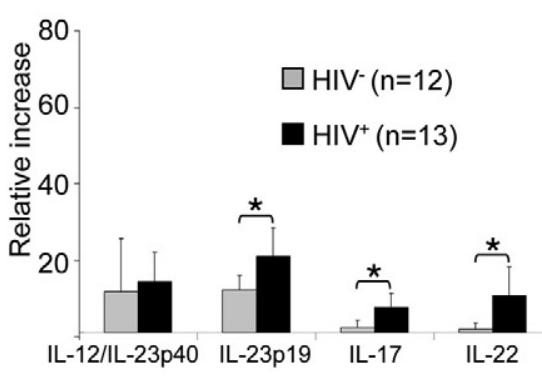

E

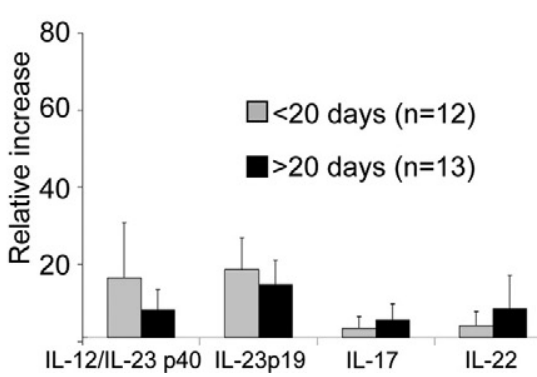

C

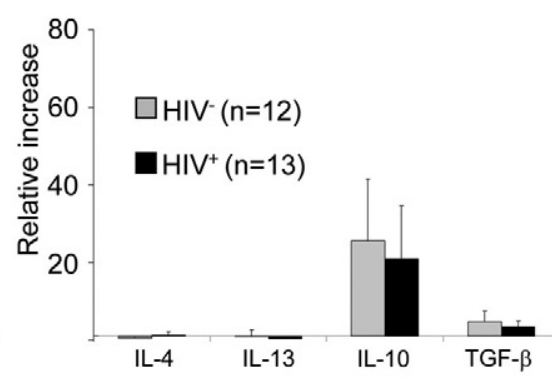

$\mathbf{F}$

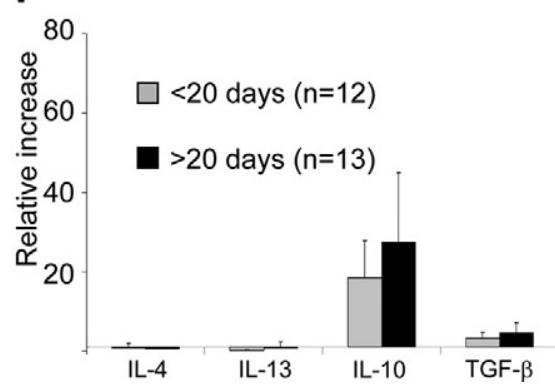

Figure 3. Quantitative RT-PCR identifies IFN- $\gamma$ as master cytokine for secondary syphilitic lesions. Quantitative RT-PCR was performed after trizol fixation of whole biopsies from secondary syphilitic lesions and analyzed for (A and $\mathbf{D})$ so-called Th1 cytokines, (B and E) Th17 cytokines, and (C and F) Th2 and regulatory cytokines. Samples were subdivided according (A-C) the patients' HIV status and (D-F) the time of persistence of the lesions. Data are normalized to $\beta 2$-microglobulin of each specimen and represent the mean values of fold changes relative to healthy skin \pm SEM. ${ }^{*} P<0.05$.

Other constituents of the syphilitic infiltrate included $\mathrm{CD}_{138^{+}}$plasma cells and small numbers of CD3 ${ }^{-} \mathrm{CD}^{+} 6^{+}$ NK cells, while CD19 ${ }^{+} \mathrm{B}$ cells and double-negative Tcells as well as inflammatory-type myeloid DCs and plasmacytoid DCs were almost absent (Figures 4A and 5A). Interestingly, CD $207^{+} \mathrm{CD} 1 \mathrm{a}^{+}$epidermal Langerhans cells were strongly decreased (Figure 5, A and B) and $\mathrm{CD}_{14}{ }^{+} \mathrm{CD} 11 \mathrm{~b}^{+}$dermal mononuclear phagocytes sharply increased in HIV-infected patients (Figure 5, A and $\mathrm{C}$ ) as compared with $\mathrm{HC}$ or $\mathrm{HIV}^{-}$patients. When analyzing differences of the cellular infiltrate according to the lesional age, we found a rather selective increase of plasma cells in syphilitic lesions persisting for more than 20 days (Figure 4E), while other leukocyte subsets remained unchanged (Figures 4E and 5D). When we subdivided samples from $\mathrm{HIV}^{+}$and $\mathrm{HIV}^{-}$syphilitic patients according to the lesional persistence ( $>20$ days and $<20$ days), we did not find statistically significant differences (data not shown). However, limited specimen numbers per group (3-4 samples each) reduce the validity of this analysis.

\section{CD8 $8^{+}$-cells as Main Source for IFN- $\gamma$ and IL-17 in Syphilitic Lesions}

To determine the cellular source of those effector cytokines whose expression was increased at the transcriptional level in syphilitic lesions, we performed multicolor immunofluorescence stainings using mAbs against the respective cytokines and defined leukocyte subpopulations. We found T-cells to be the main source of both IFN- $\gamma$ and IL-17 (Figure 6, A and B). Somewhat to our surprise, we only rarely observed $\mathrm{CD} 4^{+} \mathrm{T}$-cells to display anti-IFN- $\gamma$ and anti-IL-17 reactivity but rather identified $\mathrm{CD}^{+}{ }^{+}$-cells as the main producers of both cytokines (Figure 6, A and B). Interestingly, anti-IL-17 reactivity was occasionally found to overlap with anti-IFN- $\gamma$ staining (Figure $6 \mathrm{C}$ ). Both IFN- $\gamma$ and IL-17 were stronger expressed in lymphocytes of $\mathrm{HIV}^{+}$patients as compared with $\mathrm{HIV}^{-}$individuals (Figure 6D), which is consistent with the data obtained at the transcriptional level. These $\mathrm{CD} 3^{+} \mathrm{CD} 8^{+} \mathrm{IFN}$ $\gamma^{+} \mathrm{IL}-17^{+}$cells were localized within the upper dermal infiltrate in close contact to other leukocytes.

\section{Local Host Response of HIV Patients Fails to Control T. pallidum in Late Lesions}

Antitreponema immunostainings of paraffin-fixed sections revealed the presence of $T$. pallidum in the epidermis and dermis of syphilitic lesions of all 25 patients. Depending on whether the spirochetes were encountered horizontally or vertically they appeared as spiral or punctual structures (Figure 7A). Quantification of T. pallidum by immunohistochemistry revealed a significant increase of spirochetes within the dermis of HIV-infected patients (Figure 7B). This result was substantiated when we subjected tissue specimens of lesions from $\mathrm{HIV}^{+}$and $\mathrm{HIV}^{-}$patients to $T$. pallidum-specific quantitative RT-PCR analysis (Figure 7D). Combined evaluation of the age of the lesions and the HIV status of the patients disclosed a sharp increase of the causative pathogens of syphilis only in late lesions of HIV-infected patients, while the number of spirochetes in early lesions was comparably 
A 80

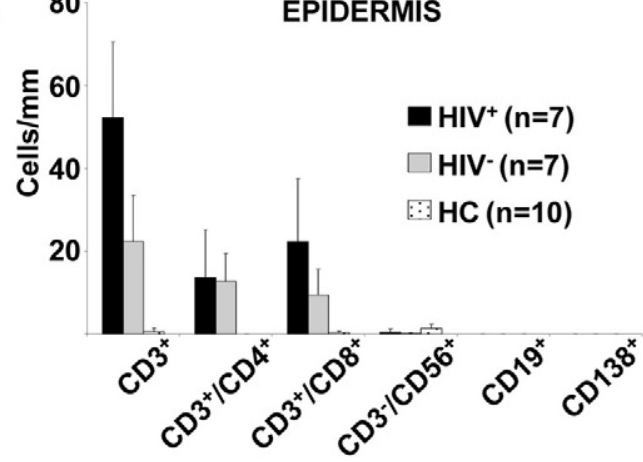

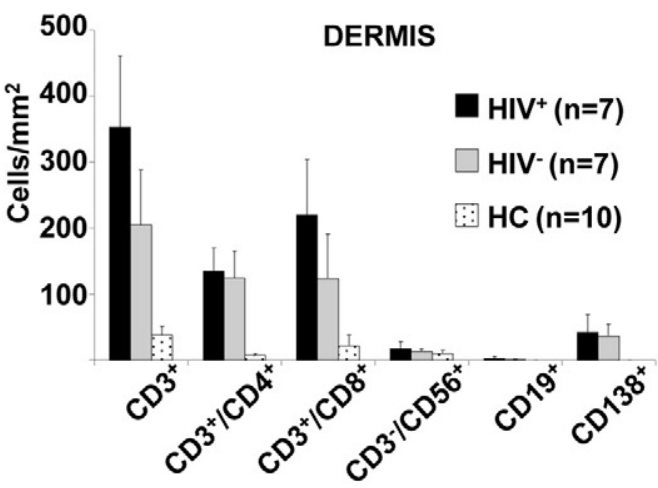

B

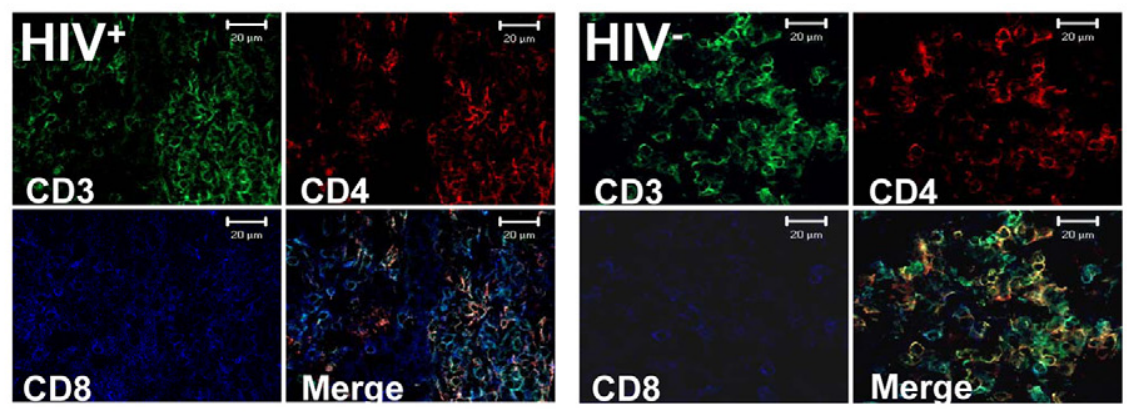

C 30 DERMIS
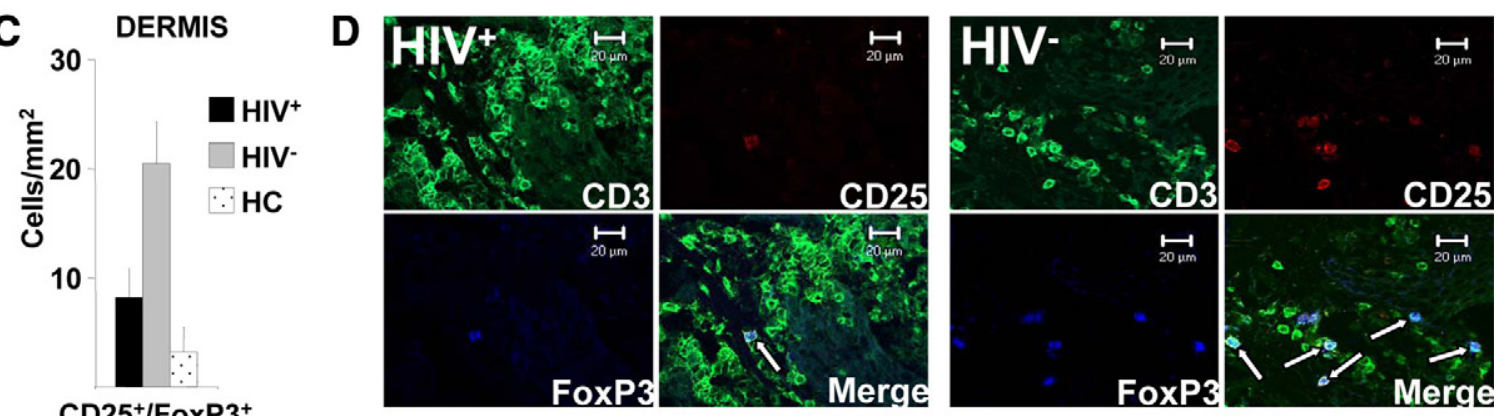

\section{$\mathrm{CD}^{+} 5^{+} / \mathrm{FoxP}^{+}$}

E

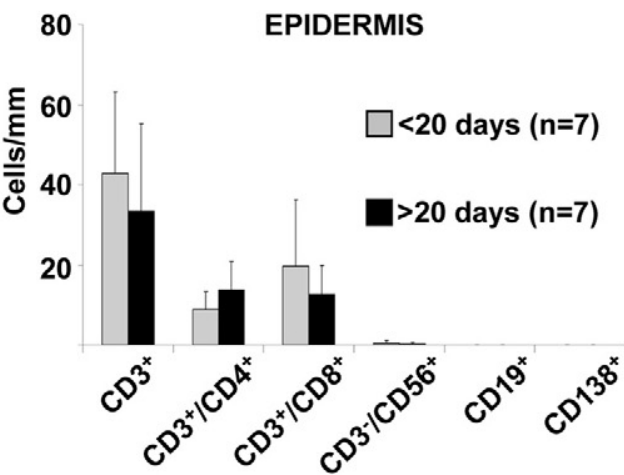

500

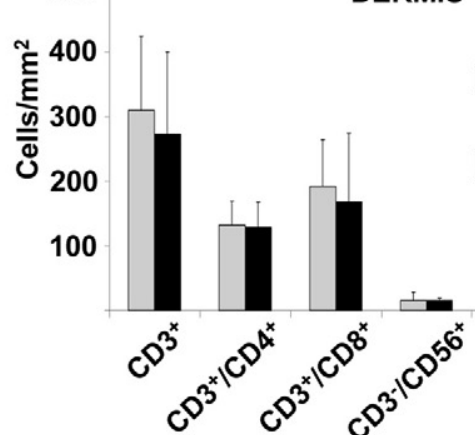

$<20$ days $(n=7)$

$>20$ days $(n=7)$

Figure 4. Alterations of the lymphocytic infiltrate in syphilitic lesions of $\mathrm{HIV}^{+}$and $\mathrm{HIV}^{-}$patients. A: Detailed quantitative in situ analysis of lymphocytes within the epidermis and dermis of secondary syphilitic lesions and normal skin from healthy controls (HC). Single and double immunofluorescence staining was performed with the indicated markers from $\mathrm{HIV}^{+}$and $\mathrm{HIV}^{-}$patients. Data are given as absolute numbers of positive cells \pm SEM. B: Triple immunofluorescence labeling of syphilitic lesions from $\mathrm{HIV}^{+}$and $\mathrm{HIV}^{-}$patients with anti-CD3 (FITC), anti-CD4 (TRITC), and anti-CD8 (APC) reveals an increase in CD8 ${ }^{+} \mathrm{T}_{-}$-cells and total T-cells in biopsies from HIV-infected patients. Original magnification, $\times 400$. C: Quantification of $\mathrm{CD} 25^{+}$FoxP $3^{+} \mathrm{T}$-cells by immunofluorescence double labeling. Data are given as absolute numbers of positive cells \pm SEM. D: Triple immunofluorescence labeling of syphilitic lesions from HIV-infected and HIV patients with anti-CD3 (FITC), anti-CD25 (TRITC), and anti-FoxP3 (Cy5) reveals decreased numbers of regulatory T-cells in HIV ${ }^{+}$patients. Arrows denote triple positive cells. Original magnification, $\times 400$. E: Quantification of cell subsets was performed by single and double immunofluorescence staining with the indicated markers. Samples were subdivided according their lesional age. Data are given as the absolute numbers of positive cells \pm SEM.

low in both $\mathrm{HIV}^{+}$and $\mathrm{HIV}^{-}$patients (Figure $7 \mathrm{C}$ ). This observation suggests that an important antitreponemal effector mechanism is impaired in late lesions of HIVinfected patients.

\section{Discussion}

The immune response against $T$. pallidum was controversially discussed in the past. After early findings suggest- 
A 40

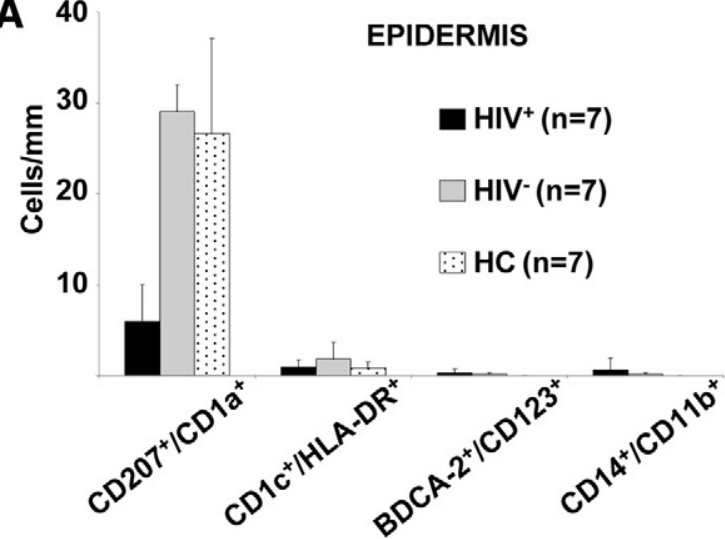

B

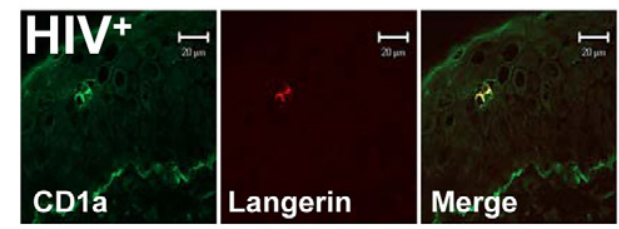

C $\mathrm{HIV}^{+}$
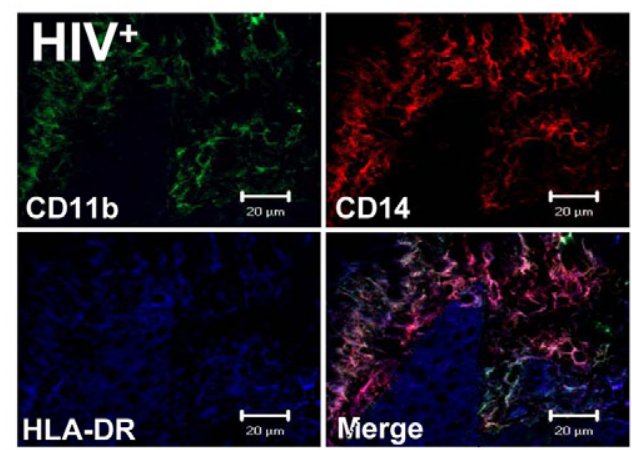

D 40

EPIDERMIS

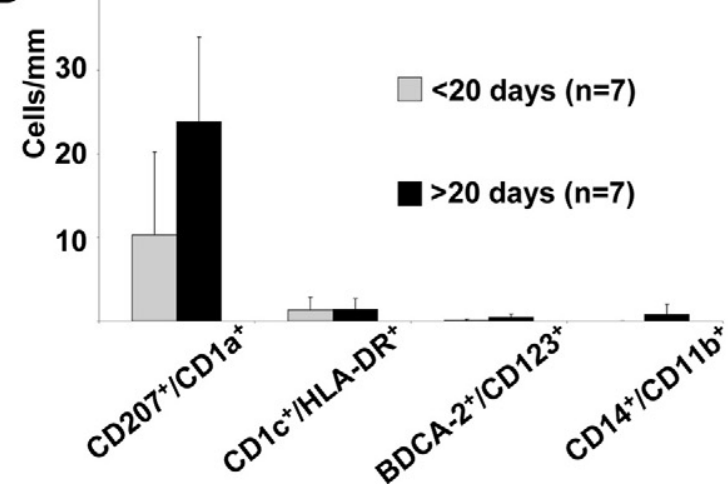

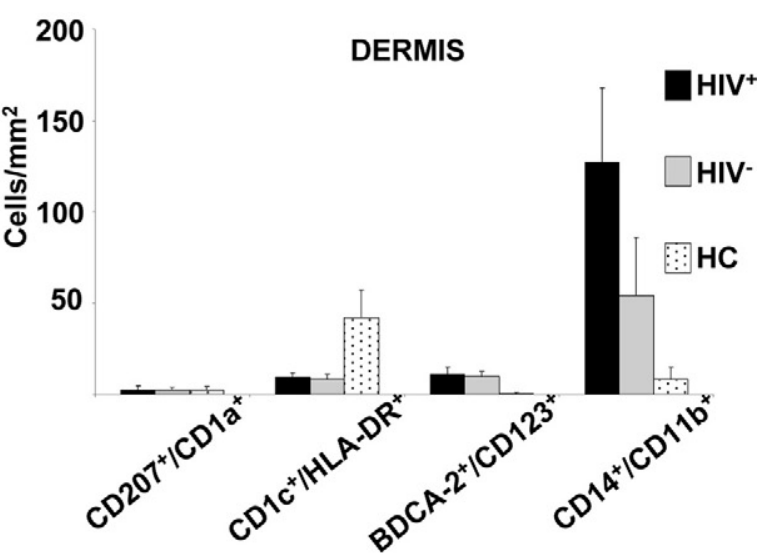
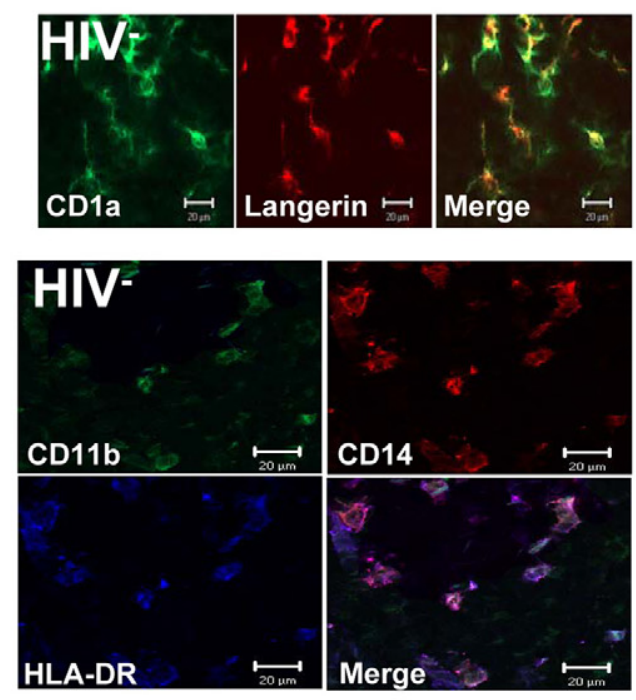

200

DERMIS

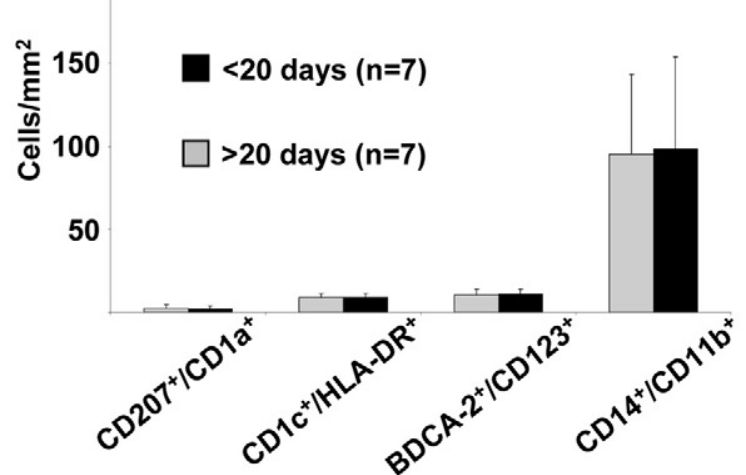

Figure 5. Dendritic cells and mononuclear phagocytes within secondary syphilitic lesions. A: Detailed quantitative $i n$ situ analysis of dendritic cells and mononuclear phagocytes within the epidermis and dermis of secondary syphilitic lesions divided according to their HIV status and normal skin from healthy controls (HC). Double immunofluorescence staining was performed with the indicated markers. Data are given as the absolute numbers of positive cells \pm SEM. B: Double immunofluorescence labeling of syphilitic lesions from $\mathrm{HIV}^{+}$and $\mathrm{HIV}^{-}$patients with anti-CD1a (FITC) and anti-Langerin (TRITC) elucidates a deficit in epidermal Langerhans cells of $\mathrm{HIV}^{+}$patients. C: Triple immunofluorescence labeling of syphilitic lesions from HIV-infected and $\mathrm{HIV}^{-}$patients with anti-CD11b (FITC), anti-CD14 (TRITC), and anti-HLA-DR (APC) reveals an increase of triple-positive mononuclear phagocytes in biopsies from HIV-infected patients. B and C: Original magnification, $\times 400$. D: Quantification of cell subsets with the indicated markers subdivided according to their lesional age. Data are given as the absolute numbers of positive cells \pm SEM.

ing that syphilitic infection results in immunosuppression, ${ }^{16}$ studies in experimental animals gave evidence for a protective humoral immunity in early syphilis. ${ }^{17,18}$ It soon became clear by rabbit models that $T$. pallidum induces a strong cellular immune response ${ }^{4}$ dominated by T-cells and classical Th1 cytokines, consistent with a delayed-type hypersensitivity reaction. ${ }^{7}$ In kinetic studies with rabbits infected with $T$. pallidum, T-cells were found to peak roughly at the same time as $T$. pallidum within the tissue. Lesional macrophages appear a few days later, which is paralleled by a sharp decline of lesional spirochetes. $^{4,19,20}$ Similarly, T-cells and macrophages are 
A

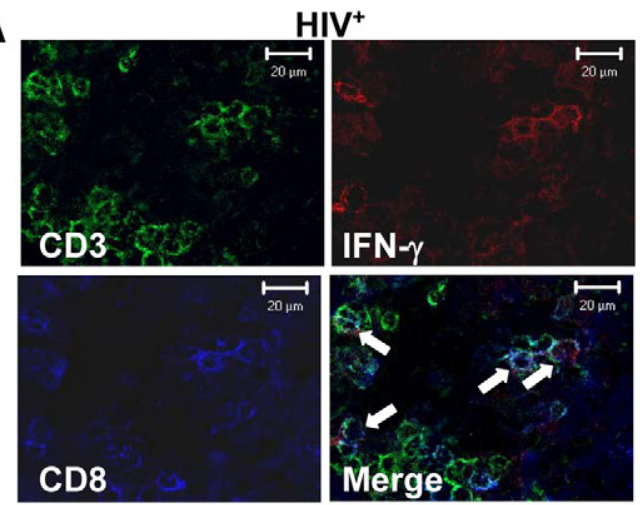

B

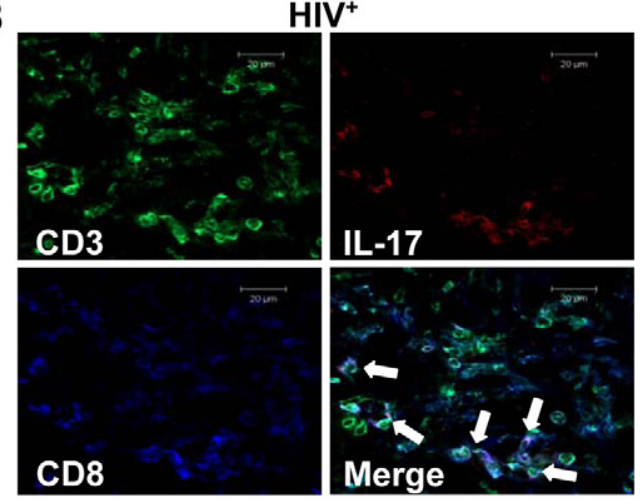

HIV-

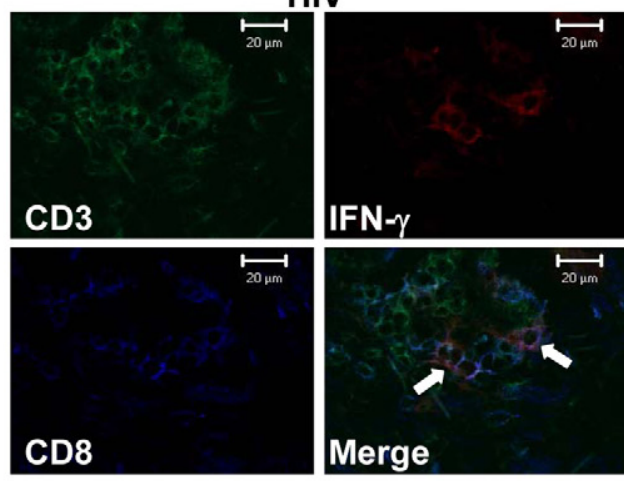

HIV

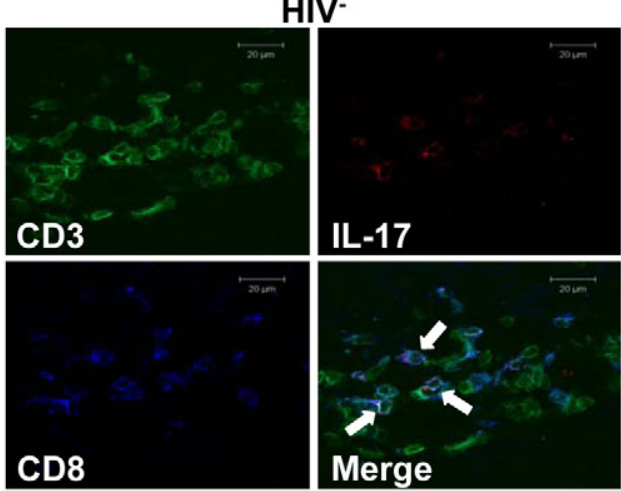

C $\mathrm{HIV}^{+}$
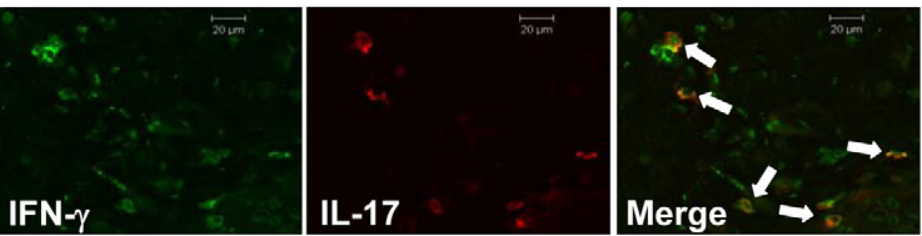

HIV-
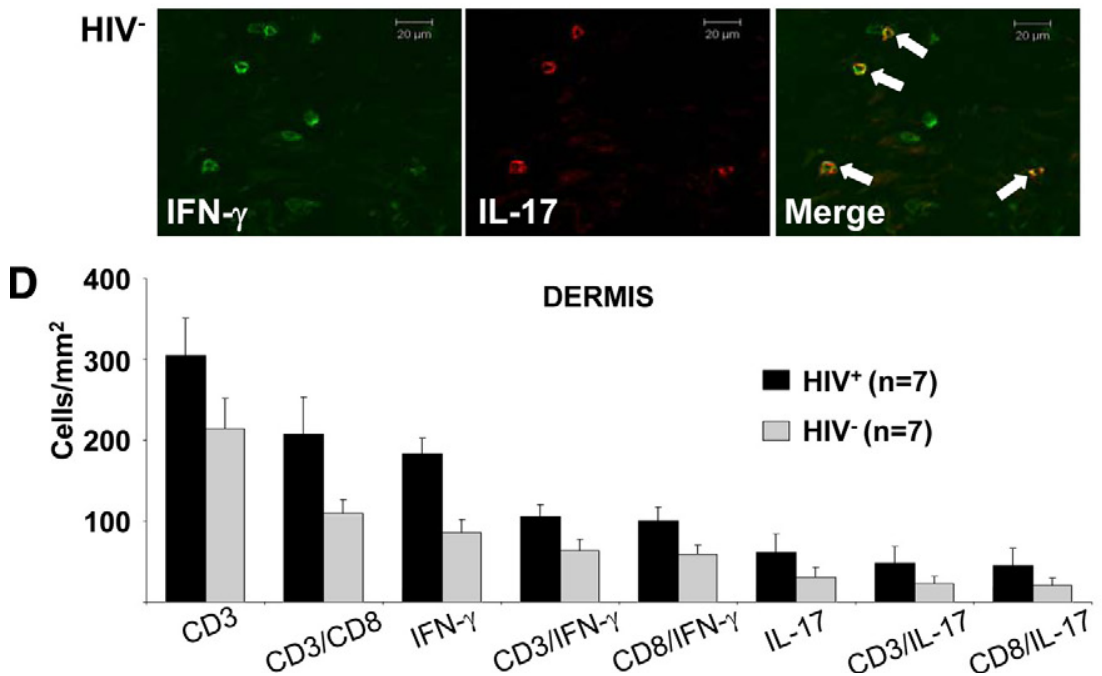

Figure 6. $\mathrm{CD}^{+}$T-cells as the main source of IFN- $\gamma$ and IL-17. Triple immunofluorescence labeling of syphilitic lesions from HIV-infected and HIV ${ }^{-}$patients with anti-CD3 (FITC), anti-CD8 (APC), and (A) anti-IFN- $\gamma$ (TRITC), or (B) anti-IL-17 (TRITC) reveals that CD8-positive T-cells are IFN- $\gamma-$ and IL-17-producing cells C: Double labeling of IFN- $\gamma$ and IL-17 showed an overlapping staining pattern. A-C: Arrows denote triple-positive cells. Original magnification, $\times 400$. D: Data are given as the absolute numbers of positive cells \pm SEM.

found in human primary chancres ${ }^{21,22}$ and secondary lesions. ${ }^{11,6}$ In functional studies phagocytosis of opsonized T. pallidum by macrophages, ${ }^{9,10}$ activated by IFN$\gamma,{ }^{10}$ has been demonstrated, and degraded T. pallidum organisms were found in phagocytic vacuoles of macrophages. $^{23,5}$ These observations combined with the fact that treponemas are extracellular bacteria gave reason to speculate that macrophages, activated by IFN- $\gamma$-pro- 
A
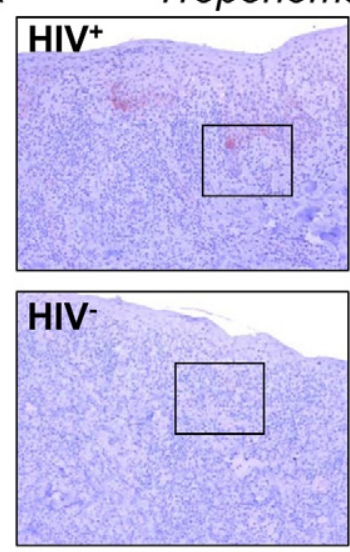

B

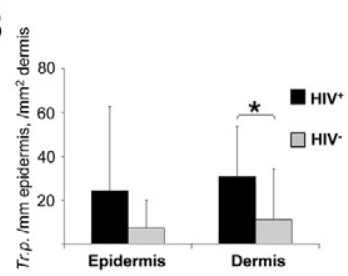

Treponema pallidum
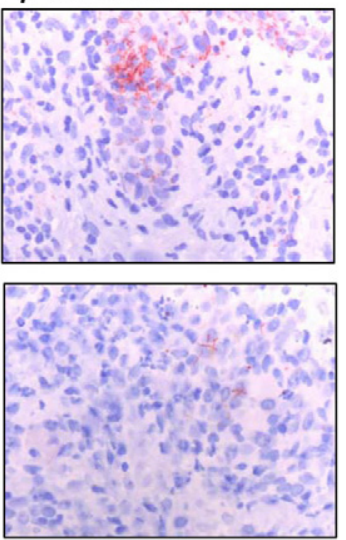

C

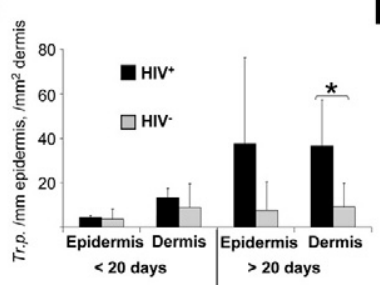

Rabbit IgG
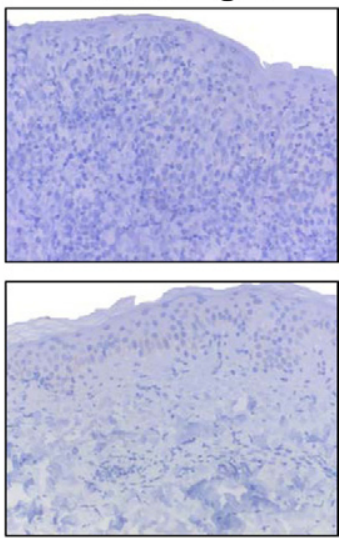

D 2.500

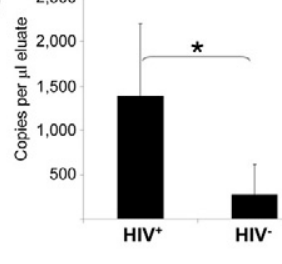

Figure 7. Increase of $T$. pallidum in late secondary syphilitic lesions. A and B: Immunohistochemistry of paraffin sections with an anti- $T$. pallidum antibody shows an increase of treponemas in HIV-infected patients. Original magnification, $\times 100$ of the total pictures and $\times 400$ of the insets. B: Quantification of treponemas in the epidermis and dermis of syphilitic patients by immunohistochemistry. C: Further splitting of the samples to early and late secondary syphilitic lesions reveals that the increase of treponemas in $\mathrm{HIV}^{+}$patients accounts only for late lesions of HIV-infected individuals. B and C: Data are given as the absolute numbers of treponemas \pm SEM. ${ }^{*} P<0.05$. D: Quantification of $T$. pallidum transcripts by quantitative RT-PCR. Data represent the mean values of copies per ml eluate \pm SEM. ${ }^{*} P<0.05$. ducing T-cells, are the pathogen-clearing cells in syphilis. The exact nature of the IFN- $\gamma$-producing T-cell subset has been a matter of debate. While CD4 ${ }^{+}$T-cells were the most likely candidates in rabbit models of syphilis infection, ${ }^{19}$ other studies indicated a possible role for $\mathrm{CD}^{+}$T-cells in providing this macrophage-activating cytokine. $^{7}$

The cellular course of events described in animals and also observed in humans infected with $T$. pallidum is similar to what we observed in our $\mathrm{HIV}^{-}$syphilitic patients. The earliest inflammatory cell was the lymphocyte, followed by neutrophils, macrophages, and plasma cells. Phenotypically, the T-cells belonged at equal parts to the $\mathrm{CD}^{+}$and $\mathrm{CD}^{+}$lineage. We now provide evidence that the antisyphilitic immune response is not only mediated by IFN- $\gamma$-only-producing T-cells but also by IFN- $\gamma$-/IL17-double positive T-cells, a phenomenon not described before in syphilis. Attention has recently focused on a new effector cell subset, termed Th17/Tc17 cells, which supposedly play an important role in the protection against extracellular bacteria, in antitumor immunity as well as in the development of autoimmune and (auto)inflammatory diseases. ${ }^{24-29}$ In hepatitis C virus-infected patients a defined subset of $\mathrm{CD}^{+} \mathrm{T}$-cells was observed to co-express IL-17 and high levels of IFN- $\gamma$, ${ }^{30}$ a phenotype consistent with what we found in syphilitic lesions especially from $\mathrm{HIV}^{+}$individuals. Thus, our data fit well to and are an extension of the concept that $T$. pallidum elicits a delayed-type hypersensitivity reaction of mainly $\mathrm{CD}^{+}$ T-cells producing IL-17 and IFN- $\gamma$, similar to what has been described for contact hypersensitivity reactions. ${ }^{26,27,29,31}$ One can speculate that these IFN- $\gamma$-/IL17-double positive $\mathrm{CD}^{+}$T-cells also play a role in the antisyphilitic host response by IL-17- and IL-22-mediated antibacterial effector functions and IFN- $\gamma$-depen- dent activation of macrophages that then clear opsonized treponemas. In addition, cytotoxic properties of $\mathrm{CD}^{+}{ }^{+}$T-cells could be responsible for tissue destruction and inflammation that is particularly pronounced in syphilitic lesions of $\mathrm{HIV}^{+}$patients. ${ }^{32-34}$ Activation of the newly discovered $\mathrm{CD}^{+}$T-cells by $T$. pallidum could take place directly via Toll-like receptor $2^{35}$ or indirectly after intracellular uptake of the bacteria by macrophages and presentation via $\mathrm{MHC}-\mathrm{I}$.

Somewhat surprising was our finding of only few IL$17^{+}$and/or IFN- $\gamma^{+} \mathrm{CD} 4^{+}$T-cells in syphilitic lesions. One can argue that i) $\mathrm{CD}^{+}{ }^{+} \mathrm{T}$-cells are needed as "helper cells" for CD8 ${ }^{+}$T-cells, ii) a substantial proportion of $\mathrm{CD}^{+}{ }^{+} \mathrm{T}$-cells has a regulatory phenotype leading to the limitation of the immune reaction against treponemas, iii) IL-17 and IFN- $\gamma$ are produced by CD4 ${ }^{+}$T-cells below the threshold of our detection system, or iv) $\mathrm{CD} 4^{+}$ T-cells are "innocent" bystander cells in the anti-treponemal immune response. The last argument is favored by the clinical observation that the severity of clinical manifestations in HIV-infected patients does not strictly correlate with their CD4 cell count, as it is the case in most opportunistic infections.

The situation in HIV-infected syphilitic patients is more difficult to explain. Although studies exist which indicate that the clinical course of syphilis is not significantly distinct between HIV-infected and -uninfected individuals, ${ }^{36,37}$ our findings of increased numbers of $T$. pallidum in lesions of $\mathrm{HIV}^{+}$patients would suggest that the antisyphilitic immune response in these individuals is not very effective, and certainly not protective. It therefore appears that IFN- $\gamma / \mathrm{IL}-17$-double-positive $\mathrm{CD}^{+}{ }^{+}$T-cells and macrophages are perhaps needed but do not suffice to eliminate $T$. pallidum. This implies that an additional effector function is absent or at least down-regulated in 
HIV-infected subjects. Different mechanisms come to mind. Exhaustion of $\mathrm{CD} 8^{+} \mathrm{T}$-cells in HIV-infected individuals ${ }^{38,39}$ could result in an accumulation of these cells as compensation mechanism, incapable of eliminating the bacteria but causing increased tissue destruction, as shown for Th17/Tc17 cells in different chronic inflammatory diseases. ${ }^{40-42}$ On the other hand it is conceivable that in HIV-infected patients reduced numbers of dermal regulatory T-cells ${ }^{43}$ and/or epidermal Langerhans cells ${ }^{44}$ with regulatory properties ${ }^{45}$ could cause an excessive, but not effective, cellular immune response. In this regard, it is noteworthy that IFN- $\gamma$-stimulated plasma cells express B7-H1 (PD-L1) and thereby inhibit T-cell functions. ${ }^{46}$ Thus, increased levels of plasma cells in late syphilitic lesions combined with elevated IFN- $\gamma$ levels could thereby create an immunosuppressive milieu resulting in diminished pathogen clearance.

The occurrence of IFN- $\gamma$-/IL-17-producing $\mathrm{CD} 8^{+} \mathrm{T}$ cells in syphilitic lesions should focus attention to this cell subset and could have implications for other infections with extracellular bacteria. Functional analysis should clarify their role in pathogen clearance and/or tissue destruction.

\section{Acknowledgment}

We thank Dr. Sheila Lukehart for helpful discussions and critical arguments.

\section{References}

1. Rockwell DH, Yobs AR, Moore MB Jr: The Tuskegee Study of Untreated Syphilis; the 30th Year of Observation. Arch Intern Med 1964, 114:792-798

2. Baker-Zander SA, Fohn MJ, Lukehart SA: Development of cellular immunity to individual soluble antigens of Treponema pallidum during experimental syphilis. J Immunol 1988, 141:4363-4369

3. Arroll TW, Centurion-Lara A, Lukehart SA, Van Voorhis WC: T-Cell responses to Treponema pallidum subsp. pallidum antigens during the course of experimental syphilis infection. Infect Immun 1999, 67:4757-4763

4. Lukehart SA, Baker-Zander SA, Lloyd RM, Sell S: Characterization of lymphocyte responsiveness in early experimental syphilis. II. Nature of cellular infiltration and Treponema pallidum distribution in testicular lesions. J Immunol 1980, 124:461-467

5. Sell S, Baker-Zander S, Powell HC: Experimental syphilitic orchitis in rabbits: ultrastructural appearance of Treponema pallidum during phagocytosis and dissolution by macrophages in vivo. Lab Invest 1982, 46:355-364

6. van Voorhis WC, Barrett LK, Nasio JM, Plummer FA, Lukehart SA: Lesions of primary and secondary syphilis contain activated cytolytic T-cells. Infect Immun 1996, 64:1048-1050

7. Van Voorhis WC, Barrett LK, Koelle DM, Nasio JM, Plummer FA Lukehart SA: Primary and secondary syphilis lesions contain mRNA for Th1 cytokines. J Infect Dis 1996, 173:491-495

8. Lukehart SA: Activation of macrophages by products of lymphocytes from normal and syphilitic rabbits. Infect Immun 1982, 37:64-69

9. Baker-Zander SA, Lukehart SA: Macrophage-mediated killing of opsonized Treponema pallidum. J Infect Dis 1992, 165:69-74

10. Lukehart SA, Miller JN: Demonstration of the in vitro phagocytosis of Treponema pallidum by rabbit peritoneal macrophages. J Immunol 1978, 121:2014-2024

11. McBroom RL, Styles AR, Chiu MJ, Clegg C, Cockerell CJ, Radolf JD: Secondary syphilis in persons infected with and not infected with
HIV-1: a comparative immunohistologic study. Am J Dermatopathol 1999, 21:432-441

12. Salazar JC, Cruz AR, Pope CD, Valderrama L, Trujillo R, Saravia NG, Radolf JD: Treponema pallidum elicits innate and adaptive cellular immune responses in skin and blood during secondary syphilis: a flow-cytometric analysis. J Infect Dis 2007, 195:879-887

13. Sellati TJ, Waldrop SL, Salazar JC, Bergstresser PR, Picker LJ, Radolf JD: The cutaneous response in humans to Treponema pallidum lipoprotein analogues involves cellular elements of both innate and adaptive immunity. J Immunol 2001, 166:4131-4140

14. Brightbill HD, Libraty DH, Krutzik SR, Yang RB, Belisle JT, Bleharski JR, Maitland M, Norgard MV, Plevy SE, Smale ST, Brennan PJ, Bloom BR, Godowski PJ, Modlin RL: Host defense mechanisms triggered by microbial lipoproteins through toll-like receptors. Science 1999, 285:732-736

15. Stary G, Bangert C, Tauber M, Strohal R, Kopp T, Stingl G: Tumoricidal activity of TLR7/8-activated inflammatory dendritic cells. J Exp Med 2007, 204:1441-1451

16. Pavia CS, Folds JD, Baseman JB: Depression of lymphocyte response to concanavalin A in rabbits infected with Treponema pallidum (Nichols strain). Infect Immun 1976, 14:320-322

17. Hanff PA, Bishop NH, Miller JN, Lovett MA: Humoral immune response in experimental syphilis to polypeptides of Treponema pallidum. J Immunol 1983, 131:1973-1977

18. Pavia CS, Niederbuhl CJ: Acquired resistance and expression of a protective humoral immune response in guinea pigs infected with Treponema pallidum Nichols. Infect Immun 1985, 50:66-72

19. Leader BT, Godornes C, VanVoorhis WC, Lukehart SA: CD4+ lymphocytes and gamma interferon predominate in local immune responses in early experimental syphilis. Infect Immun 2007, 75: 3021-3026

20. Sell S, Gamboa D, Baker-Zander SA, Lukehart SA, Miller JN: Host response to Treponema pallidum in intradermally-infected rabbits: evidence for persistence of infection at local and distant sites. J Invest Dermatol 1980, 75:470-475

21. Engelkens HJ, ten Kate FJ, Judanarso J, Vuzevski VD, van Lier JB, Godschalk JC, van der Sluis JJ, Stolz E: The localisation of treponemes and characterisation of the inflammatory infiltrate in skin biopsies from patients with primary or secondary syphilis, or early infectious yaws. Genitourin Med 1993, 69:102-107

22. Tosca A, Lehou J, Hatjivasiliou M, Varelzidis A, Stratigos JD: Infiltrate of syphilitic lesions before and after treatment. Genitourin Med 1988, 64:289-293

23. Jepsen OB, Hougen $\mathrm{KH}$, Birch-Andersen A: Electron microscopy of treponema pallidum Nichols. Acta Pathol Microbiol Scand 1968, $74: 241-258$

24. Louten J, Boniface K, de Waal Malefyt R: Development and function of TH17 cells in health and disease. J Allergy Clin Immunol 2009, 123:1004-1011

25. Ortega C, Fernandez AS, Carrillo JM, Romero P, Molina IJ, Moreno JC, Santamaria M: IL-17-producing CD8+ T lymphocytes from psoriasis skin plaques are cytotoxic effector cells that secrete Th17related cytokines. J Leukoc Biol 2009, 86:435-443

26. He D, Wu L, Kim HK, Li H, Elmets CA, Xu H: IL-17 and IFN-gamma mediate the elicitation of contact hypersensitivity responses by different mechanisms and both are required for optimal responses. J Immunol 2009, 183:1463-1470

27. Kish DD, Li X, Fairchild RL: CD8 T-cells producing IL-17 and IFNgamma initiate the innate immune response required for responses to antigen skin challenge. J Immunol 2009, 182:5949-5959

28. Hinrichs CS, Kaiser A, Paulos CM, Cassard L, Sanchez-Perez L, Heemskerk B, Wrzesinski C, Borman ZA, Muranski P, Restifo NP: Type 17 CD8+ T-cells display enhanced anti-tumor immunity. Blood 2009, 114:596-599

29. Zhao Y, Balato A, Fishelevich R, Chapoval A, Mann DL, Gaspari AA: Th17/Tc17 infiltration and associated cytokine gene expression in elicitation phase of allergic contact dermatitis. Br J Dermatol 2009, 161:1301-1306

30. Billerbeck E, Kang YH, Walker L, Lockstone H, Grafmueller S, Fleming V, Flint J, Willberg CB, Bengsch B, Seigel B, Ramamurthy N, Zitzmann N, Barnes EJ, Thevanayagam J, Bhagwanani A, Leslie A, Oo YH, Kollnberger S, Bowness P, Drognitz O, Adams DH, Blum HE, Thimme R, Klenerman P: Analysis of CD161 expression on human 
CD8 + T cells defines a distinct functional subset with tissue-homing properties. Proc Natl Acad Sci USA 2010, 107:3006-3011

31. He D, Wu L, Kim HK, Li H, Elmets CA, Xu H: CD8+ IL-17-producing $T$ cells are important in effector functions for the elicitation of contact hypersensitivity responses. J Immunol 2006, 177:6852-6858

32. Schöfer H, Imhof M, Thoma-Greber E, Brockmeyer NH, Hartmann M, Gerken G, Pees HW, Rasokat H, Hartmann H, Sadri I, Emminger C, Stellbrink HJ, Baumgarten R, Plettenberg A: Active syphilis in HIV infection: a multicentre retrospective survey. The German AIDS Study Group (GASG) Genitourin Med 1996, 72:176-181

33. Don PC, Rubinstein R, Christie S: Malignant syphilis (lues maligna) and concurrent infection with HIV. Int J Dermatol 1995, 34:403-407

34. Gregory N, Sanchez M, Buchness MR: The spectrum of syphilis in patients with human immunodeficiency virus infection. J Am Acad Dermatol 1990, 22:1061-1067

35. Lee SM, Joo YD, Seo SK: Expression and function of TLR2 on CD4 versus CD8 T cells. Immune Netw 2009, 9:127-132

36. Farhi D, Benhaddou N, Grange P, Zizi N, Deleuze J, Morini JP, Gerhardt P, Krivine A, Avril MF, Dupin N: Clinical and serologic baseline and follow-up features of syphilis according to HIV status in the post-HAART era. Medicine (Baltimore) 2009, 88:331-340

37. Rolfs RT, Joesoef MR, Hendershot EF, Rompalo AM, Augenbraun $\mathrm{MH}$, Chiu M, Bolan G, Johnson SC, French P, Steen E, Radolf JD, Larsen S: A randomized trial of enhanced therapy for early syphilis in patients with and without human immunodeficiency virus infection. The Syphilis and HIV Study Group N Engl J Med 1997, 337:307-314

38. Barber DL, Wherry EJ, Masopust D, Zhu B, Allison JP, Sharpe AH, Freeman GJ, Ahmed R: Restoring function in exhausted CD8 T cells during chronic viral infection. Nature 2006, 439:682-687

39. Kaufmann DE, Walker BD: PD-1 and CTLA-4 inhibitory cosignaling pathways in HIV infection and the potential for therapeutic intervention. J Immunol 2009, 182:5891-5897
40. Miossec P: IL-17 and Th17 cells in human inflammatory diseases. Microbes Infect 2009, 11:625-630

41. Nograles KE, Zaba LC, Guttman-Yassky E, Fuentes-Duculan J Suarez-Farinas M, Cardinale I, Khatcherian A, Gonzalez J, Pierson KC, White TR, Pensabene C, Coats I, Novitskaya I, Lowes MA, Krueger JG: Th17 cytokines interleukin (IL)-17 and IL-22 modulate distinct inflammatory and keratinocyte-response pathways. Br J Dermatol 2008, 159:1092-1102

42. Kleinschek MA, Boniface K, Sadekova S, Grein J, Murphy EE, Turner SP, Raskin L, Desai B, Faubion WA, de Waal Malefyt R, Pierce RH, McClanahan T, Kastelein RA: Circulating and gut-resident human Th17 cells express CD161 and promote intestinal inflammation. J Exp Med 2009, 206:525-534

43. Jiao Y, Fu J, Xing S, Fu B, Zhang Z, Shi M, Wang X, Zhang J, Jin L, Kang F, Wu H, Wang FS: The decrease of regulatory T-cells correlates with excessive activation and apoptosis of CD8+ T-cells in HIV-1-infected typical progressors, but not in long-term non-progressors. Immunology 2009, 128:e366-e375

44. Tschachler E, Groh V, Popovic M, Mann DL, Konrad K, Safai B, Eron L, DiMarzo Veronese F, Wolff K, Stingl G: Epidermal Langerhans cells-a target for HTLV-III/LAV infection. J Invest Dermatol 1987, 88:233-237

45. Romani N, Ebner S, Tripp CH, Flacher V, Koch F, Stoitzner P: Epidermal Langerhans cells-changing views on their function in vivo. Immunol Lett 2006, 106:119-125

46. Liu J, Hamrouni A, Wolowiec D, Coiteux V, Kuliczkowski K, Hetuin D, Saudemont A, Quesnel B: Plasma cells from multiple myeloma patients express B7-H1 (PD-L1) and increase expression after stimulation with IFN-gamma and TLR ligands via a MyD88- TRAF6-, and MEK-dependent pathway Blood 2007, 110:296-304 